РОЗВИТОК ФРАНЧАЙЗИНГОВОГО БІЗНЕСУ В УКРАЇНІ ТА СВІТІ

\title{
DEVELOPMENT OF FRANCHISING BUSINESS IN UKRAINE AND IN THE WORLD
}

УДК 339.187.44(477)(045)

DOI: https://doi.org/10.32843/bses.46-2

\section{Давидюк Л.п.}

к.е.н., доцент кафредри економіки та міжнародних відносин

Вінницький торговельно-економічний інститут

Київського національного торговельноекономічного університету

\section{Davidyuk Ludmila}

Vinnitsa Trade and Economic Institute Kyiv National University of Trade and Economics

\begin{abstract}
Статтю присвячено актуальним питанням організації та фрункціонування фрранчайзингу в Україні. Наведено результати дослідження розвитку фрранчайзингового бізнесу у світі та в Україні. Розкрито сутність основних фрранчайзингових відносин у сучасних умовах. Проведено аналіз країн - світових лідерів за кількістю фрранчайзерів та діяльності світових компаній - лідерів у фрранчайзинговому бізнесі. Визначено, що лідерами фрранчайзингового бізнесу в Європі є Великобританія, Німеччина, Франція та Польща. Проаналізовано галузеву структуру фрранчайзингового бізнесу в розрізі країн таких, як США, Німеччина, Франція та Україна. Відзначено динамічний та стабільний розвиток фрранчайзингу в Україні як один із найбільш перспективних видів бізнесу в Україні. Підкреслено, що фрранчайзинговий бізнес сконцентрований лише у великих містах. Обгрунтовано перспективи розвитку фрранчайзингу в Україні, наведено ймовірні шляхи вирішення проблем галузі.

Ключові слова: міжнародний франчайзинг, міжнародний бізнес, франшиза, франчайзер, світовий ринок.
\end{abstract}

Статья посвящена актуальным вопросам организации и функционирования фрранчай- зинга в Украине. Приведены результаты исследования развития фрранчайзингового бизнеса в мире и в Украине. Раскрыта сущность основных фрранчайзинговых отношений в современных условиях. Проведен анализ стран - мировых лидеров по количеству франчайзеров и деятельность мировых компаний - лидеров в сорере франчайзингового бизнеса. Определено, что лидерами франчайзингового бизнеса в Европе являются Великобритания, Германия, Франция и Польша. Проанализирована отраслевая структура фрранчайзингового бизнеса в разрезе таких стран, как США, Германия, Франция и Украина. Отмечено динамичное и стабильное развитие фрранчайзинга в Украине как одного из наиболее перспективных видов бизнеса в Украине. Подчеркнуто, что фрранчайзинговый бизнес сконцентрирован только в крупных городах. Обоснованы перспективы развития фрранчайзинга в Украине, приведены возможные пути решения проблем отрасли.

Ключевые слова: международный фрранчайзинг, международный бизнес, фрраншиза, фрранчайзер, мировой рынок.

The article deals with topical issues about organization and functioning franchising in Ukraine. Franchising is one of the popular business models for entrepreneurs and companies interested in diversifying into other business in Ukraine. Franchises are available on a per license basis for a specific city, region, or the country. Presented are the results of research on the development of franchising business in the world and in particular in Ukraine. Revealed is the essence of the main franchise relations in modern conditions. The analysis of the leading countries of the world by the number of franchisors and conducted is the activity of the world leading companies in the franchising business. It is determined that the leaders of franchising business in Europe are Great Britain, Germany, France and Poland. Analyzed is the branch structure of franchising business by countries such as USA, Germany, France and Ukraine. Noted is dynamic and stable development of franchising in Ukraine as one of the most promising types of business in Ukraine. Most Ukrainian franchises operate in the services and restaurant subsectors. It is emphasized that franchising business is concentrated only in big cities. In addition, most of franchise units are situated in the biggest Ukrainian cities - such as Kharkov, Dnepropetrovsk, Donetsk, Odessa and Lviv. But many towns are not yet acquainted with franchising. There is a tendency of glutting the cities and companies redirect in openings of franchise units also in smaller towns. The Ukrainian market offers many opportunities for international franchising. However, as an entrepreneurial activity, franchising encounters the same general barriers, as the establishments of small and medium businesses do. These include the whole complex of taxes, high credit rates, crisis of nonpayment, unstable legislation, and very strict control under the subjects of entrepreneur activity by the state. The investment climate remains the major obstacle for franchises in Ukraine. For that substantiated are prospects for the development of franchising in Ukraine and outlined are the possible ways of solving branch problems.

Key words: international franchising, international business, franchise, franchisor, world market.

Постановка проблеми. В умовах процесів глобалізації та інтернаціоналізації економік світу розвиток фрранчайзингового бізнесу у світі є одним із найпрогресивніших. Міжнародний франчайзинг як одна з форм бізнесу сьогодні досить динамічно розвивається, оскільки фрраншиза є більш простим способом проникнення підприємств на світові ринки і не потребує значних інвестиційних ресурсів для започаткування справи. Розвиток сучасного бізнесу в Україні відбувається в умовах економічної кризи. Сьогодні характерні масштабні розриви соціально-економічного, інвестиційно-фрінансового та організаційно технологічного характеру, а також асиметрія у відносинах власності, розподілі, у системі управління. Для вітчизняної економіки фрранчайзинг $є$ відносно новим явищем, тоді як у розвинутих країнах фрранчайзинг сторіччями практикувався як засіб забезпечення потреб суспільства в різних послугах.
Отже, для того щоб розробити стратегію виведення українського бізнесу зі стану кризи, потрібно застосувати таку фрорму підприємництва, як фрранчайзинг. На жаль, забезпечення цієї діяльності стикається $з$ великою кількістю дискусійних питань правового та економічного регулювання, тому сьогодні є актуальними організація та фрункціонування орранчайзингу в Україні.

Аналіз останніх досліджень і публікацій. Протягом останніх років фрранчайзинг став об'єктом багатьох наукових робіт. Дослідженнями, присвяченими такій формі ділового співробітництва, як фрранчайзинг, займалися такі зарубіжні автори, як Ж. Дельта, Ф. Котлер, Ж. Ламбен, Ф. Росса. Це питання досліджували вітчизняні науковці Л.М. Побоченко [8], О.О. Мартиненко [6], Н.В. Безрукова [1], М.О. Тонюк [10]. Економічні аспекти наукового забезпечення франчайзингу відображено у роботах О. Суковатого [15], О. Корольчука 
[16], С. Махнуши [17] та ін. У них розкрито суть франчайзингу як прогресивної фрорми ведення бізнесу, його основні різновиди, структуру, можливі ризики застосування тощо.

Незважаючи на достатню кількість наукових досліджень щодо сутності фрранчайзингу, постає питання постійного аналізу перспектив подальшого розвитку фрранчайзингу на території України 3 урахуванням світового досвіду, встановлення чинників, що перешкоджають цьому розвитку.

Постановка завдання. Метою статті $€$ окреслення основних тенденцій розвитку франчайзингу в Україні з урахуванням світового досвіду, а також визначення основних проблем та перспектив його розвитку.

Виклад основного матеріалу дослідження. Сьогодні фрранчайзинг визнаний у світі як найбільш прогресивна форма ведення бізнесу. Переваги від фрранчайзингу вигідні для підприємців, що розпочинають свій бізнес, оскільки вони суттєво знижують ризик невдачі та втрати коштів.

Незважаючи на загальну значимість ролі фрранчайзингу в провідних країнах світу, серед науковців немає єдиного погляду на цю діяльність. Загальне визначення Міжнародної асоціації фрранчайзингу: «Франчайзинг - це договірні відносини між фрраншизодавцем і фрраншизоодержувачем, де фрраншизодавець пропонує або зобов'язується виявити постійний інтерес до діяльності франшизоодержувача в таких сорерах, як ноу-хау та навчання персоналу, тоді як фрраншизоодержвуач здійснює власну діяльність під спільним фрірмовим найменуванням, форматом чи процесом, яким володіє фрраншизодавець, та вклав або вкладе значні інвестиції у це підприємство із власних ресурсів» [1].

Нині міжнародний франчайзинг діє у понад 140 країнах світу. Найбільшої популярності фрранчайзинг набув у США, Франції, Німеччині, Великобританії та Польщі. Свідченням цього $€$ кількість брендів, які розвивають свої мережі через фрранчайзинг. Американська компанія FranchiseDirect опублікувала рейтинг «ТОП-10 світових фрраншиз» після детального вивчення брендів з усього світу. Десятку лідерів рейтингу склали американські фрраншизи у сфрерах громадського харчування та готельно-ресторанного бізнесу (табл. 1) [11].

Перше місце незмінно в останні роки займає фрраншиза McDonald's. Сьогодні мережа включає орієнтовно 36900 об'єктів. 2018 р. виявився успішним для фрраншиз KFSIBurgerKing, які зайняли другу і третю позиції рейтингу, тим самим змістили фрраншизу SUBWAY® на четверте місце. Тільки один із франчайзерів у лідируючій десятці є представником роздрібної торгівлі - мережа магазинів 7Eleven. Мережа заснована в 1927 р. у Даласі (Техас, США), є дочірнім підприємством японської Seven-ElevenJapanCo.Ltd, яка, своєю чергою, належить японському холдингу Seven\&lHoldingsCo. Сьогодні мережа 7 Eleven включає 63 тис магазинів у 17 країнах світу (більше ніж 58,5 тис із них працюють за фрраншизою). Проривом першої десятки рейтингу стала компанія Hertz, яка піднялася за 2018 р. відразу на 18 позицій [11].

На рис. 1 представлено сучасну структуру фрранчайзингових підприємницьких організацій в економіці США. Галузеві пріоритети фрранчайзингу в економіці США визначають у принципі ті сорери підприємницької діяльності, які в сучасних умовах є провідними галузями фрункціонування фрранчайзингових мереж. Так, фрранчайзинг успішно адаптувався в галузі громадського харчування (50\% фрранчайзингових організацій знаходяться саме у цій сфрері), реалізації продовольчих товарів, готельних послуг тощо [2].

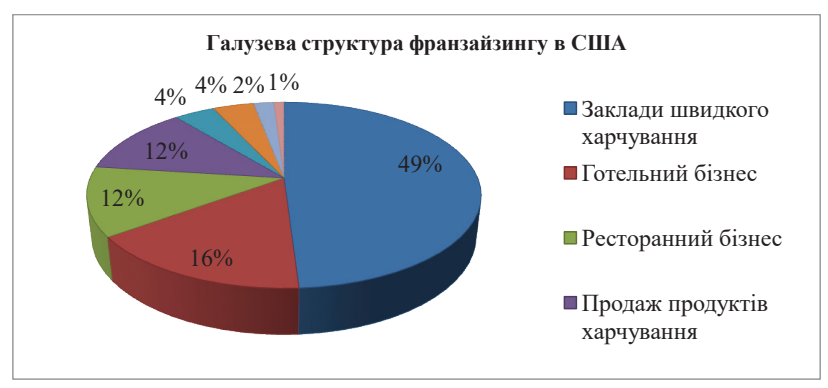

Рис. 1. Галузева структура франчайзингу в США

Топ-10 франшиз у світі в 2018 році

Таблиця 1

\begin{tabular}{|c|c|c|c|c|c|}
\hline Ранг & Назва фрраншизи & Рік заснування & Країна & Вид діяльності & Кількість об'єктів \\
\hline 1 & McDonald's & 1955 & США & Громадське харчування & 36900 \\
\hline 2 & KFC & 1930 & США & Громадське харчування & 20605 \\
\hline 3 & BurgerKing & 1954 & США & Громадське харчування & 15740 \\
\hline 4 & SUBWAY® & 1965 & США & Громадське харчування & 44780 \\
\hline 5 & 7 Eleven & 1927 & США & Роздрібна торгівля & 63000 \\
\hline 6 & Hertz & 1923 & США & Автосервіс, автодилерство & 9700 \\
\hline 7 & PizzaHut & 1958 & США & Громадське харчування & 16410 \\
\hline 8 & MarriottInternational & 1927 & США & Готельно-ресторанний бізнес & 5975 \\
\hline 9 & WyndhamHotelsandResorts & 1981 & США & Готельно-ресторанний бізнес & 8035 \\
\hline 10 & HiltonHotels\&Resorts & 1919 & США & Готельно-ресторанний бізнес & 4925 \\
\hline
\end{tabular}

Джерело: складено за даними FranchiseDirect 
До найдорожчих фрраншиз США належать: Hampton Hotels (готелі), Anytime Fitness (фрітнессалони), Subway (фраст-фруд), JackintheBox (фрастфуд), Supercuts (перукарські послуги), Jimmy John's Gourmet Sandwiches (фраст-фруд), Servpro (клінінг), Denny'slnc. (фраст-фруд), PizzaHutInc. (фраст-сруд), 7-ElevenInc (продукти) [1].

У Західній Європі фрранчайзинг менш поширений, аніж у США. Його частка в роздрібному товарообороті становить $30 \%$. Усього в країнах $€ С$ працюють близько 4500 франчайзингових мереж та 180 тис фрранчайзі, їхній річний оборот перевищує 150 млрд дол. США [5]. Лідерами фрранчайзингового бізнесу в Європі $€$ Великобританія, Німеччина, Франція та Польща.

Другою у світі країною за обсягом експорту фрранчайзингу $є$ Німеччина. За кількістю франчайзерів i фрранчайзі Німеччина займає передову позицію у сорері розвитку фрранчайзингу серед європейських країн. На рис. 2 представлено галузеву структуру фрранчайзингу в Німеччині [6]. Загальна кількість фрранчайзингових систем досягла 598 установ та 28 тис фрранчайзі. Щорічний приріст галузі становить приблизно 7\% для фрранчайзерів і 17\% для фрранчайзі, що свідчить про високу динаміку розвитку фрранчайзингового сектору країни.

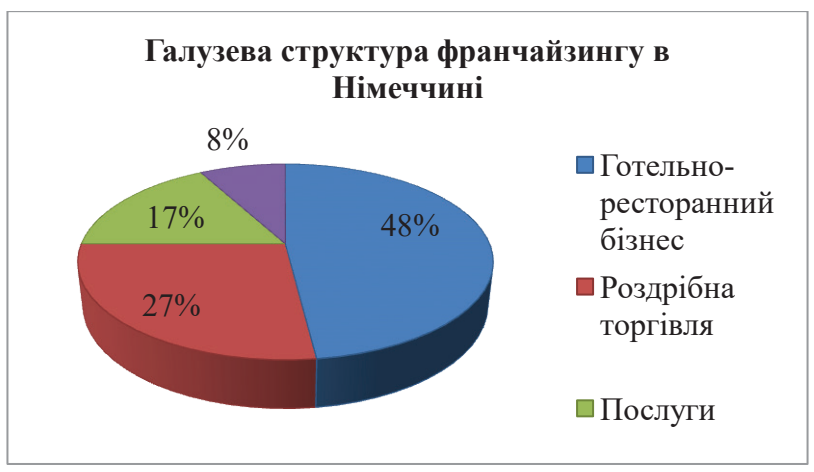

Рис. 2. Галузева структура фрранчайзингу в Німеччині

На третьому місці за розвитком франчайзингового бізнесу знаходиться Велика Британія. Сьогодні в країні фрункціонує 936 фрранчайзингових мереж із понад 20 тис фрранчайзі, кількість яких у середньому зростає на 6\% щороку. Франчайзинг поширений переважно в таких галузях, як персональні послуги, ресторани швидкого харчування, будівництво та роздрібна торгівля.

У Франції зареєстровано всього 34 фрранчайзингові мережі. Французи охоплюють близько 40\% усього європейського фрранчайзингового ринку, ємність якого оцінюється у 32-35 млрд дол. США.

У Франції характерне домінування національних фрранчайзингових операторів [5].

Польський ринок фрранчайзингу в період 2005-2018 рр. демонстрував постійну позитивну динаміку зростання. Незважаючи на світову еконо-

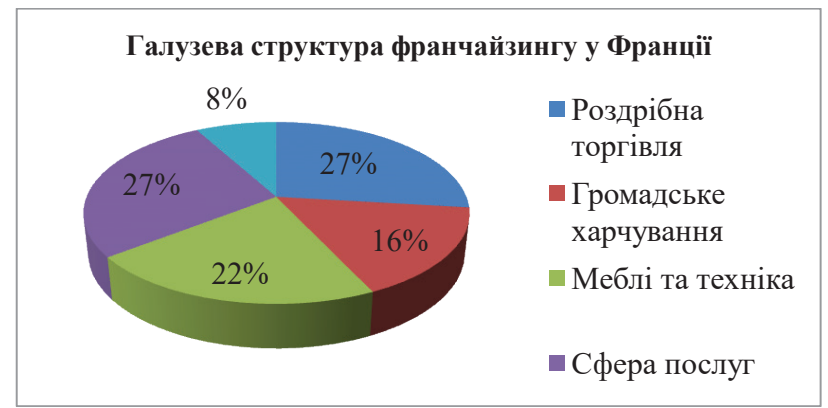

Рис. 3. Галузева структура франчайзингу у Франції

мічну кризу 2008-2009 рр., яка призвела до негативних наслідків практично в усіх сорерах ведення бізнесу, на франчайзинг у Польщі вона не мала жодного впливу. Найширший вибір перевірених бізнес-ідей розташовувався у ціновому діапазоні від 21 до 50 тис злотих [7].

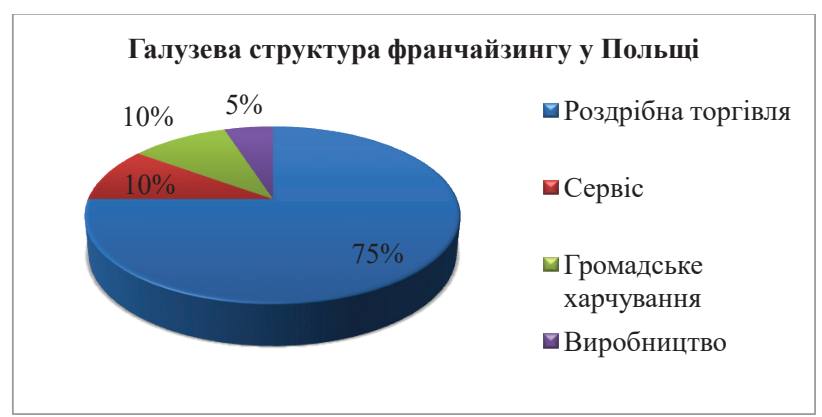

Рис. 4. Галузева структура фрранчайзингу у Польщі

Аналізуючи ситуацію на українському ринку, слід відзначити динамічний та стабільний розвиток фрранчайзингу, який $є$ одним із найбільш перспективних видів бізнесу в Україні. За даними Асоціації франчайзингу в Україні, сьогодні в країні працює понад 23 тис фрранчайзингових точок i близько 700 фрранчайзерів. 65\% ринку займають національні фрраншизи. На рис. 5 представлено галузеву структуру франчайзингу в Україні [12].

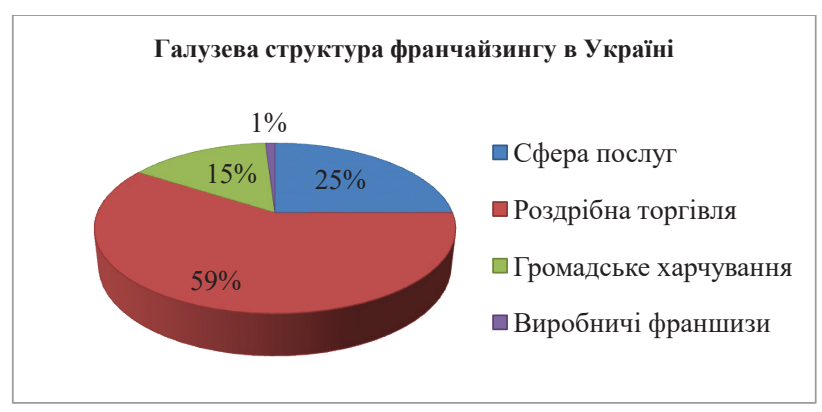

Рис. 5. Галузева структура франчайзингу в Україні

Найбільш відомі українські фрранчайзери, які довели працездатність своїх проектів, - мережі ресторанів Mafia, PESTOCAFÉ, «Хінкальня», пекарні-кав'ярні LvivCroissants i «Насолода», 
«Франс.уа», фраст-фруд CHIKENHUT і FreshLine, піцерія PIZZA CELENTANO, мережі супермаркетів «Наш Край» і NOVUS, магазини солодощів ручної роботи «Львівська майстерня шоколаду» і «Веселі карамелі», бутіки дизайнерського одягу ANDRE TAN [13]. На рис. 6 представлено динаміку фрранчайзингових мереж в Україні.

Незважаючи на домінуючу роль в Україні вітчизняних фрранчайзерів, на території нашої держави представлені також фрранчайзингові мережі 3 Росії, Польщі, Нідерландів, Франції, США, Німеч- чини, Великої Британії та інших країн. Присутність в Україні іноземних компаній як фрранчайзерів має певні позитивні наслідки. Функціонування іноземних фрранчайзерів дає змогу вітчизняним підприємствам із часом перейняти успішний досвід ведення діяльності в умовах фрранчайзингових відносин, достатній для більш широкого розвитку договірної системи внутрішнього фрранчайзингу в Україні. Крім того, діяльність іноземних фрранчайзерів сприяє постачанню на вітчизняний ринок нових товарів і послуг. Найбільш поширеними

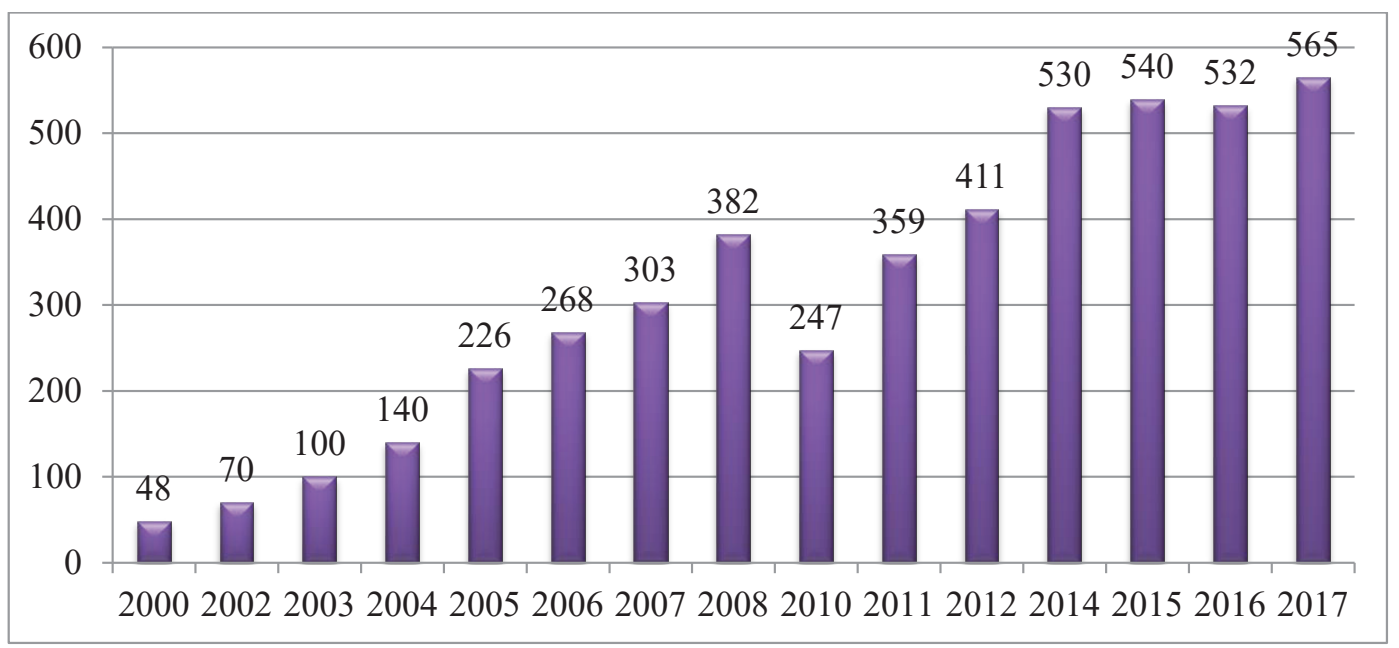

Рис. 6. Динаміка фрранчайзингових мереж в Україні в 2001-2017 рр. (одиниць)

Джерело: складено за даними звіту «Франшизи в Україні стійкі до кризи»

Таблиця 2

Перелік найбільш привабливих фрраншиз в Україні та їх характеристика

\begin{tabular}{|c|c|c|c|c|}
\hline $\begin{array}{c}\text { Назва ТМ } \\
\text { фрранчайзиигової } \\
\text { мережі }\end{array}$ & Сфера діяльності & Вступний платіж & Роялті & Термін окупності \\
\hline «Наш Край» & Торгівля/ Супермаркет & Відсутній & $3,5 € /$ кв. м & Від 5 міс. \\
\hline «Винахідник» & Діти/Технічна студія & $\$ 37500$ & 10000 грн & 36-40 мiс. \\
\hline MortimerEnglishClub & Діти/Школа англ. мови & Від 90000 грн & $10-12 \%$ & 12-18 мic. \\
\hline Vianor & Шинний центр & $\$ 625$ & 5000 грн/рік & 12-36 mic. \\
\hline «Піца Челентано» & $\begin{array}{c}\text { Громадське харчування/ } \\
\text { Піцерія }\end{array}$ & За домовленістю & $1,50 \%$ & 30-36 міс. \\
\hline «Франс.уа» & Громадське харчування & 50 000-75 000 грн & Відсутнє & 4-11 мiс. \\
\hline «Булочная № 1» & Хлібопекарня/Булочна & 25 000-75 000 грн & Відсутнє & 4-10 міс. \\
\hline MAFIA & Громадське харчування & 1445000 грн & $5 \%$ на міс & 24-36 мiс. \\
\hline RoyalCarwash & Автомийка & 20 000-70 000 грн & 500 грн./міс & 1-3 мiс. \\
\hline «Наминайко» & Громадське харчування & 100 грн & Відсутнє & 4-6 мic. \\
\hline NewYorkStreetPizza & $\begin{array}{c}\text { Громадське харчування/ } \\
\text { Піцерія }\end{array}$ & 130000 грн & 2\% від обороту & 12-24 мic. \\
\hline «Поехали с нами» & Турагенція & 20 000-35 000 грн & $1-2 \%$ & 10-12 мiс. \\
\hline «Імідж» & $\begin{array}{c}\text { Торгівля/Магазин } \\
\text { косметики }\end{array}$ & 100000 грн & $4 \%$ & 24-30 мiс. \\
\hline Veliki.ua & Послуги для населення & 500-1 500 грн & 500-800 грн. & 3-18 мic. \\
\hline CoffeeLife & $\begin{array}{c}\text { Громадське харчування/ } \\
\text { Кав'ярня }\end{array}$ & 250000 грн & 5\% щомісяця & 6-36 мiс. \\
\hline Join UP! & Турагенція & 8000 грн & $\begin{array}{l}\text { Залежно від } \\
\text { міста }\end{array}$ & 5-7 міс. \\
\hline
\end{tabular}

Джерело: складено за даними Каталогу фрраншиз [3] 
стають фрраншизи для малого бізнесу із вкладенням інвестицій у розмірі не більшому за 2 млн грн. У табл. 2 представлено десять популярних орраншиз в Україні у 2015 р. Ефрективність цієї фрорми ведення бізнесу полягає у тому, що фрранчайзинг - надійний спосіб зменшення операційних ризиків, а також збільшення шансів тривалого виживання компаній. Із кожним роком кількість як українських, так і закордонних фрранчайзерів збільшується, що свідчить про ефективність використання фрранчайзингу.

Найбільшою українською франшизою «продуктового» сегмента стала мережа магазинів «Наш Край», в якої більше 80\% точок є франчайзинговими. Ця мережа розширилася до 139 магазинів і впевнено утримує звання найбільшої фрранчайзингової мережі в сегменті FMSG. Мережа магазинів «Наш Край» працює у трьох фрорматах: «експрес», «магазин біля дому» і «супермаркет».

За кількістю франчайзингових об'єктів найбільшими мережами в Україні $€$ «Наша Ряба» (понад 2 500), «Гаврилівські курчата» (600), «Форнетті» (500). Найбільшою мережею за обсягом фрранчайзингових точок зі сорери харчування $€$ CELENTANO PIZZA (160 точок) [14].

Незважаючи на низький рівень частки франчайзингу в Україні порівняно із зарубіжними показниками, майже кожного року прослідковується позитивна тенденція приросту фрранчайзерів. Франчайзинговий ринок надає великі переваги для економіки України. Він може стати початком для розвитку дрібних і спільних підприємств, які займатимуться інноваційною діяльністю.

Більшість українських фрранчайзингових систем сконцентрована у столиці, і лише невеликий відсоток фрраншиз започатковуються 3 великих регіональних центрів. Окрім того, більшість фрранчайзингових підрозділів розташована у найбільших містах України - Харкові, Дніпрі, Донецьку, Одесі та Львові. Але багато міст ще не знайомі 3 франчайзингом. Існує тенденція перенасичувати міста та компанії, які переадресовують відкриття підрозділів фрранчайзингу також у менших містах.

Український ринок пропонує багато можливостей для міжнародного франчайзингу. Однак як підприємницька діяльність фрранчайзинг стикається 3 тими ж загальними бар'єрами, що й установи малого та середнього бізнесу. Сюди входять увесь комплекс податків, високі кредитні ставки, криза неплатежів, нестабільне законодавство та дуже суворий контроль із боку держави над об'єктами підприємницької діяльності. Інвестиційний клімат залишається головною перешкодою для фрраншиз в Україні.

Розвиток фрранчайзингу в Україні значно гальмується такими проблемами:

- фінансово-кредитного характеру (складність процедури кредитування малих підприємств);
- незахищеність українських фрранчайзерів у фрранчайзинговій співпраці з іноземними представниками;

- брак знань у підприємців щодо можливостей такого способу ведення бізнесу, як фрранчайзинг;

- значне обмеження розвитку малого бізнесу податковими нормами, внаслідок чого підприємці змушені шукати обхідні шляхи у здійсненні паушального платежу та роялті;

- недосконалість нормативно-законодавчої бази стосовно фрранчайзингових відносин.

Нині в Україні відсутнє спеціальне законодавство, що регулює фрункціонування фрранчайзингової моделі бізнесу, проте фрранчайзингові відносини набувають усе більшої популярності та охоплюють такі сорери бізнесу, як громадське харчування, послуги, будівництво, роздрібна торгівля тощо [10].

Висновки з проведеного дослідження. Отже, лідерами фрранчайзингового бізнесу на міжнародній арені є країни з високим рівнем економічного розвитку. Досвід таких країн, як США, Німеччина та Велика Британія, свідчить про те, що фрранчайзинг може виступати як ефективна модель розширення існуючого бізнесу. Перш за все, запорукою успішного розвитку фрранчайзингових мереж країни $€$ економічна стабільність, за якої власники бізнесу будуть спроможні інвестувати в розвиток власного бізнесу, а населення матиме високий рівень платоспроможності.

Підсумовуючи, варто зазначити, що франчайзинг в Україні $€$ перспективним напрямом економічної діяльності та в найближчі роки ми будемо спостерігати зростання цього сегменту. Франчайзинг має низку як переваг, так і недоліків, які дають змогу знизити операційні витрати та підвищити ефективність виробничої діяльності, що особливо важлива для України в сучасних умовах. Як для фрранчайзера, так і для фрранчайзі існують ризики недобросовісної поведінки до та після укладення договору. У країнах ЄС сторони керуються принципом добросовісності, що є позитивним прикладом для України.

Щоб прискорити розвиток фрранчайзингу на українському ринку, необхідно ратиорікувати закон «Про фрранчайзинг», де права фрранчайзера та франчайзі будуть захищені; активізувати діяльність консультаційних та бізнес-центрів із підготовки бізнес-планів, поради з управління та розроблення системи банківського кредитування та лізингу для фрранчайзі під гарантію фрранчайзер (франчайзер також може надати кредит фрранчайзі на вигідних умовах); приділяти більше уваги в установах, університетах, коледжах технологіям фрранчайзингу та досліджувати світовий досвід фрранчайзингу на практиці.

Франчайзинг в умовах кризи буде розвиватися. Однак середні фрранчайзери, які працюють без 
жорсткої системи з франчайзі, можуть мати низку проблем, які в гіршому варіанті будуть причиною ліквідації деяких компаній. У період економічної кризи краще довіряти великим фрранчайзинговим мережам, які піклуються про своїх партнерів.

\section{БІБЛІОГРАФІЧНИЙ СПИСОК:}

1. Безрукова Н.В. Міжнародний фрранчайзинг як фрорма освоєння світових ринків: особливості розвитку тавплив на світовий валовий продукт. Економічнийпроcmip. 2016. № 106. C. 16-25. URL: http://www.irbis-nbuv. gov.ua/cgi-bin/irbis_nbuv/cgiirbis_64.exe?I21DBN=LIN $\mathrm{K} \& \mathrm{P} 21 \mathrm{DBN}=\mathrm{UJRN} \& Z 21 \mathrm{ID}=\& S 21 \mathrm{REF}=10 \& S 21 \mathrm{CNR}=2$ $0 \& S 21 S T N=1 \& S 21 F M T=A S P \_$meta $\& C 21 C O M=S \& 2$ S21P03=FILA=\&2_S21STR=ecpros_2016_106_4 (дата звернення: 23.10.2019).

2. Добрянська Ю.О. Дослідження сучасного стану фрранчайзингу в Україні та світі. Вісник Миколаївського національного університету імені B.О. Сухомлинського. 2015. № 7. С. 122-126. URL: http://global-national.in.ua/archive/7-2015/28.pdf (дата звернення: 23.10.2019).

3. Каталог фрраншиз. URL: http://franchisegroup. com.ua/catalog/1 (дата звернення: 23.10.2019).

4. Лазоренко Т., Фролова А. Розвиток фрранчайзингу у світі та в Україні. Соціально-економічні проблеми і держава. 2017. Вип. 2(17). С. 199-207. URL : https://sepd.tntu.edu.ua/index.php/en/arch ive/20/516-2017-12-23-09-22-45 (дата звернення: 23.10.2019).

5. Макарчук К.О. Фактори впливу на розвиток міжнародного бізнесу у країнах Східної Азії. Вісник економіки транспорту і промисловості. 2016. № 56. C. 159-169. URL: http://www.irbis-nbuv.gov.ua/ cgi-bin/irbis_nbuv/cgiirbis_64.exe? (дата звернення: 23.10.2019).

6. Мартиненко О.О. Світовий досвід використання фрранчайзингу як ефективної моделі розширення бізнесу. Бізнес Інорорм. 2018. № 9. С. 253-258. URL: http://nbuv.gov.ua/UJRN/binf_2018_9_38 (дата звернення: 23.10.2019).

7. Побоченко Л.М. Розвиток фрранчайзингового бізнесу в країнах Європи. Стратегія розвитку України. 2016. № 1. С. 57-64. URL: https://conf.ztu. edu.ua/wp-content/uploads/2018/09/45.pdf (дата звернення: 23.10.2019).

8. Романчук К.В. Операції фрранчайзингу: європейський досвід та українські реалії. Ефективна економіка. 2016. № 12. URL: http://www.economy.nayka. com.ua/?op=1\&z=5302 (дата звернення: 23.10.2019).

9. Тонюк М.О. Франчайзинг як особлива форма організації та ффункціонування бізнесу в Україні. Економіка і суспільство. 2017. № 9. С. 687-689. URL: http://economyandsociety.in.ua/journal-9/16-stati-9/921tonyuk-m-о (дата звернення: 23.10.2019).

10. ТОП-100 мировых фрраншиз по итогам 2018 года. URL: https://www.forbes.ru/rating/363769-reytingfranshiz-2018 (дата звернення: 23.10.2019).

11. Франчайзинговий ринок України сьогодні. URL: https://ffc.expert/uk/blog/franchajzingovyj-rynokukrainy-segodnya/https://www.forbes.ru/rating/363769reyting-franshiz-2018 (дата звернення: 23.10.2019).
12. Чего стоит ожидать от рынка фрранчайзинга в 2018 году? URL: https://community.com.ua/ ru/news-community/chego-stoit-ozhidat-ot-ryinkafranchayzinga-v-2018-godu/https://www.forbes.ru/ rating/363769-reyting-franshiz-2018 (дата звернення: 23.10.2019)

13. Забаштанська Т. Історичні аспекти розвитку фрранчайзингу в діяльності посередницьких підприємств. Проблеми і перспективи розвитку національної економіки. 2016. № 1(5). С. 36-44. URL: http://ppeu.stu.cn.ua/tmppdf/184.pdf (дата звернення: 23.10.2019).

14. Суковатий О.Е. Франчайзинг як інноваційна модель розвитку бізнесу. Проблеми науки. 2007. № 3. C. 18-23. URL: http://molodyvcheny.in.ua/files/ conf/eko/33nov2018/33nov2018.pdf (дата звернення: 23.10.2019).

15. Корольчук О.П. Франчайзинг як спосіб активізації інтеграції вітчизняного бізнесу у глобальні виробничі та збутові мережі. Економіка і фрінанси підприємств. 2011. № 5. С. 176-185.

16. Махнуша С.М. Франчайзинг як елемент стратегії закріплення бренду підприємства. Механізм регулювання економіки. 2004. № 1. С. 105-110.

\section{REFERENCES:}

1. Bezrukova N. V. (2016) Mizhnarodnyi franchaizynh yak forma osvoiennia svitovykh rynkiv: osoblyvosti rozvytku ta vplyv na svitovyi valovyi produkt [International franchising as a form of development of world markets: development features and impact on the global gross product] Ekonomichnyi prostir [Economic space] (electronic journal), no. 106, pp. 16-25. Available at: http://www.irbis-nbuv.gov.ua/cgi-bin/irbis_nbuv/ cgiirbis 64.exe?I21DBN=LINK\&P21DBN=UJRN\&Z2 $1 \mathrm{ID}=\& \mathrm{~S} 21 \mathrm{REF}=10 \& \mathrm{~S} 21 \mathrm{CNR}=20 \& \mathrm{~S} 21 \mathrm{STN}=1 \& \mathrm{~S} 21 \mathrm{~F}$ $\mathrm{MT}=\mathrm{ASP}$ meta\&C21COM=S\&2_S21P03=FILA=\&2 S21STR=écpros 2016_106_4 (accessed 23 October 2019).

2. Dobrianska Yu. O. (2015) Doslidzhennia suchasnoho stanu franchaizynhu v Ukraini ta sviti [Research on the current state of franchising in Ukraine and in the world] Mykolaivskyi natsionalnyi universytet imeni V.O. Sukhomlynskoho [Nikolaev National University of Sukhomlinsky] (electronic journal), no. 7, pp. 122-126. Available at: http://global-national.in.ua/archive/7-2015/28.pdf (accessed 23 October 2019).

3. Kataloh franshyz [Franchise catalog] Available at: http://franchisegroup.com.ua/catalog/1 (accessed 23 October 2019).

4. Lazorenko T., Frolova A. (2017) Rozvytok franchaizynhu u sviti ta $v$ Ukraini [Development of franchising in the world and in Ukraine] Sotsialno-ekonomichni problemy i derzhava [Socio-economic problems and the state] (electronic journal), vol. 2 (17), pp. 199-207. Available at: https:sepd.tntu.edu.ua/index. php/en/arc hive/20/516-2017-12-23-09-22-45 (accessed 23 October 2019).

5. Makarchuk K. O. (2016) Faktory vplyvu na rozvytok mizhnarodnoho biznesu u krainakh Skhidnoi Azii [Factors influencing the development of international business in East Asian countries] Visnyk ekonomiky transportu i promyslovosti [Bulletin of Economics of Transport and Industry] (electronic journal), 2016, no. 56, 
pp. 159-169. Availbale at: http://www.irbis-nbuv.gov.ua/ cgi-bin/irbis_nbuv/cgiirbis_64.exe? (accessed 23 October 2019).

6. Martynenko O. O. (2018) Svitovyi dosvid vykorystannia franchaizynhu yak efektyvnoi modeli rozshyrennia biznesu [Worldwide experience in using franchising as an effective business expansion model] BiznesInform. [Businessinform](electronic journal), no. 9, pp. 253-258. Available at: http://nbuv.gov.ua/ UJRN/binf_2018_9_38 (accessed 23 October 2019).

7. Pobochenko L. M. (2016) Rozvytok franchaizynhovoho biznesu $v$ krainakh Yevropy [Development of franchising business in European countries] Stratehiia rozvytku Ukrainy [Ukraine's Development Strategy] (electronic journal), no 1, pp. 57-64. Available at: https://conf.ztu.edu.ua/wp-content/uploads/2018/09/45. pdf (accessed 23 October 2019).

8. Romanchuk K. V. (2016) Operatsii franchaizynhu: Evropeiskyi dosvid ta ukrainski realii [Franchising operations: European experience and Ukrainian realities] Efektyvna Ekonomika [Effective Economy] (electronic journal), no. 12, Available at: http://www.economy.nayka. com.ua/?op=1\&z=5302 (accessed 23 October 2019).

9. Toniuk M. O. (2017) Franchaizynh yak osoblyva forma orhanizatsii ta funktsionuvannia biznesu v Ukraini [Franchising as a special form of business organization and operation in Ukraine]. Ekonomika i suspilstvo [Economy and society] (electronic journal), no. 9, pp. 687-689. Available at: http://economyandsociety.in.ua/journal9/16-stati-9/921-tonyuk-m-o (accessed 23 October 2019).

10. TOP-100 myrovykh franshyz po ytoham 2018 hoda [TOP-100 world franchises in 2018] Available at: https://www.forbes.ru/rating/363769-reyting-franshiz-2018 (accessed 23 October 2019).

11. Franchaizynhovyi rynok Ukrainy sohodni [Franchise market of Ukraine today] Available at: https://ffc.expert/uk/blog/franchajzingovyj-rynokukrainy-segodnya/https://www.forbes.ru/rating/363769reyting-franshiz-2018 (accessed 23 October 2019).

12. Cheho stoyt ozhydat ot rynka franchaizynha v 2018 hodu? [What should you expect from the franchise market in 2018?] Available at: https://community.com.ua/ru/news-community/chegostoit-ozhidat-ot-ryinka-franchayzinga-v-2018-godu/ https://www.forbes.ru/rating/363769-reyting-franshiz-2018 (accessed 23 October 2019).

13. Zabashtanska T. (2016) Istorychni aspekty rozvytku franchaizynhu $v$ diialnosti poserednytskykh pidpryiemstv [Historical aspects of franchising development in the activity of intermediary enterprises] Problemy i perspektyvy rozvytku natsionalnoi ekonomiky [Problems and prospects of national economy development] (electronic journal), no. 1(5), pp. 36-44. Available at: http://ppeu.stu.cn.ua/tmppdf/184.pdf (accessed 23 October 2019).

14. Sukovatyi O. E. (2007) Franchaizynh yak innovatsiina model rozvytku biznesu [Franchising as an innovative model of business development] Problemy nauk [Problems of Science], no. 3, pp. 18-23. Available at: http://molodyvcheny.in.ua/files/conf/eko/ 33nov2018/33nov2018. pdf (accessed 23 October 2019).

15. Korolchuk O. P. (2011) Franchaizynh yak sposib aktyvizatsii intehratsii vitchyznianoho biznesu u hlobalni vyrobnychi ta zbutovi merezhi [Franchising as a way of intensifying the integration of domestic business into the global production and marketing networks] Ekonomika $i$ finansy pidpryiemstv, no. 5, pp. 176-185.

16. Makhnusha S. M. (2004) Franchaizynh yak element stratehii zakriplennia brendu pidpryiemstva [Franchising as an element of the branding strategy of an enterprise] Mekhanizm rehuliuvannia ekonomiky, no. 1, pp. 105-110. 